\title{
Türk Çocuklarının Bilişsel Sayı Temsilinin Çinli, Fransız, Japon, Koreli, İsveçli ve Amerikalı Yaşıtlarıyla Karşılaştırılması
}

\author{
Sinan Olkun* Hande Reçber Aslıhan Ata \\ Eren Özer Özhan Çelebi
}

ÖZ. Yapılan uluslararası araştırmalar Doğu Asyalı çocukların Amerikalı çocuklara göre matematikte daha başarılı olduklarını göstermektedir. $\mathrm{Bu}$ araştırmaların bazılarında Doğu Asya dillerinin çocuklarda matematiksel düşüncenin gelişimine özellikle onluk taban sistemi ve bilişsel sayı temsiline olan etkisini gösteren deliller bulunmaktadır. Bu nedenle dilin sayısal kavramları temsil etme özelliklerinin Doğu Asyalı öğrencilerin matematik başarısında önemli bir etken olabileceği ileri sürülmüştür. Bu çalışmanın amacı; dil özellikleri Batı dilleri ve Doğu Asya dilleri arasında olan Türkçenin bu açıdan etkisini araştırmaktır. Eğer ileri sürülen hipotez doğru ise Türk çocukları Batı ve Doğu Asya dillerini konuşan çocukların arasında bir performans göstermelidir. Bulgular Türk çocuklarının Batı dillerini konuşanlardan çok az daha iyi performans gösterdiklerini ancak Uzakdoğulu çocukların çok gerisinde olduklarını göstermektedir. Dilin matematik öğrenmede minimal bir etkiye sahip olabileceği sonucuna ulaşılmıştır. Ayrıca Türk öğrencilerin PISA ve TIMSS gibi çalışmalarda çok alt sıralarda oldukları da düşünüldüğünde dilin yanında başka etkenlerin daha baskın olabileceği ileri sürülebilir.

Anahtar Sözcükler: Bilişsel sayı temsili, Doğu Asya ve Batı dilleri, onluk taban sistemi.

*Prof. Dr. Ankara Üniversitesi, Eğitim Bilimleri Fakültesi, Cebeci, Ankara, Türkiye. E-posta: sinanolkun@gmail.com 


\title{
Turkish Children's Cognitive Representation of Number in Comparison to Children in China, France, Japan, Korea, Sweden, and United States
}

\author{
Sinan Olkun* Hande Reçber Aslıhan Ata \\ Eren Özer Özhan Çelebi
}

\begin{abstract}
Cross-national studies demonstrate that the East Asian students are more successful relative to their Western counterparts in mathematics. In these studies, there are some evidences indicating the effect of East Asian numerical language on mathematical thinking, especially on cognitive representation of number and understanding of base-ten concepts. It is hypothesized that language characteristics on representing numerical concepts could be an important factor in East Asian students' success. The aim of this study was to add Turkey, whose numerical language characteristics are between East Asian and Western language groups, to these research studies. According to our hypothesis, Turkish students are expected to perform at a level between East Asian and Western students. It was found that Turkish students performed slightly better than Western students, but much lower than all East Asian students in the study. So, it is concluded that language seems to be a minimal factor in mathematical thinking and learning. Also, when it is considered that Turkey is below all of these countries in cross-national test results such as TIMSS, PISA, it can be claimed that apart from language there might be other factors for mathematical performance cross-nationally.
\end{abstract}

Keywords: Cognitive number representation, East Asian and Western languages, Base ten system.

*Prof. Dr. Ankara University, Faculty of Educational Sciences, Cebeci, Ankara, Turkey. E-mail: sinanolkun@gmail.com 
Turkish Children's Cognitive Representation of Number in Comparison ... 81

\section{INTRODUCTION}

Cross-national studies demonstrate that far Asian countries are the most successful countries in mathematics. They are followed by the Northern European countries, then the United States and then the developing countries including Turkey (TIMSS, 2007, 2003, 1999; PISA, 2009, 2003). These results have directed especially American scientists to do comparative research on mathematical thinking and performance of far Asian and Western countries. The research, which compares far Asian and Western students' mathematical performances, generally indicates that the differences arise from home and school experiences (Hess, Chang, \& McDevitt, 1987). But, after it is found that there are differences even in pre-school period (Geary, Bow-Thomas, Liu, \& Siegler, 1996), researchers started to look for some other reasons, such as linguistic differences, in recent years.

The number names in far Asian languages represent the structure of base-ten number system. For instance, the number words after 10 are translated as ten-one, ten-two, ..., ten-nine, two-ten, two-ten-one, ... , twoten-nine, three-ten, ... etc. However, there is a less systematic structure in Western languages. For instance, it goes like ten, eleven, twelve, thirteen, fourteen,... nineteen, twenty... in English. Eleven and twelve are completely random. Thirteen, fourteen etc. are in reverse order and have a different sound (i.e., four-teen instead of ten-four). Also 10 is "ten" while it is alone, but it is "teen" between 10 and 20 and "ty" in tens. Therefore, some researchers claimed that Asian students have an advantage over others on cognitive representations of numbers, understanding base-ten and place value, because of the differences in representing numbers in their languages.

Fuson and Kwon (1992a) found that the structure of Asian number words supported Korean students' use of decomposition as a strategy for adding and subtracting. The Korean Language supports the children to decompose numbers based on 10 . For instance, to solve $6+7$, the child might decompose 7 into $4+3$, and then get $6+4+3$, so get $10+3$. According to Fuson (1990), American children perceive numbers as numerals stand side by side. For example, they perceive the " 1 " in " 15 " as " 1 " only, but not as a " 10 ". On the other hand, almost all of the Korean children are aware of the place value of the numerals in a number. Fuson and Kwon (1992b) studied Korean children's understanding of trading process in multi-digit addition and subtraction in another research, and they compared the results with American children. They found that Korean children can even do the subtraction with 3-digit numbers, whose last two digits are zero. They were very much aware of the meaning of the trading process compared to their American counterparts. 
Miura, Okamoto, Vlahovic-Stetic, Kim and Han (1999), claimed that the concept of fraction is also easier to understand in far Asian languages. For example 1/3 is expressed as "one third" in English, whereas it is "sam bun un il" (translated as "of three parts one"). There is a "third" instead of "three" in English, but it is directly "sam" which is 3 in Korean. This fraction is read "üçte-bir" in Turkish, which can be translated as "one out of three" into English. In this respect Turkish is far more similar to far Asian languages. In their research, Miura et al. (1999) found that Korean children were better in understanding the concept of fraction than their age-mates in United States, and Croatia.

Whereas these studies focused on the effects of language, cultural characteristics may also cause great cross-national differentiations (Geary et al., 1996; Zhou et al., 2005). Geary (1996), studied on the causes of crossnational differentiations in mathematics performance. He classified the causes as intelligence, language, schooling and cultural valuation. $\mathrm{He}$ concluded that there was no significant difference between the far Asian and Western children in terms of intelligence. He thought that language provides some advantages but the main factor is school experiences. He further stated that school experiences arise from cultural valuation. When the systems of education in Japan and China are investigated, some differences could be found which support this argument. For example, in TIMSS (1999) it is stated that "the NCTM standards are a mile wide, but an inch deep"; the curricula in Japan and China are both wide and deep (Judson, 1999). Mathematics education is valued very much and it is taught seriously by the teachers in these Asian countries.

Another study, which shows the effect of culture, has been done with Chinese-American, American-American and Taiwanese-American families (Huntsinger, Jose, Liaw \& Ching, 1997). The children of Chinese-American and Taiwanese-American families were found to be more successful in mathematics than the children of American-American families. When looked through, it is seen that these families value mathematics education more than the American-American families, supply more encouragement for mathematics-related activities to their children and these children are more imperturbable, calm, so more patient in formal education culturally.

The aim of the current study was to add Turkish data to Miura, Okamoto, Kim, Chang, Steere and Fayol's (1994) research which investigated possible effect of language on understanding place value and base-ten concepts. Miura et al. (1994) compared Chinese, French, Japanese, Korean, Swedish and American first graders' cognitive representation of numbers. Students were given Base 10 blocks (units and tens) and asked to construct numbers with these blocks. The ratios of using tens were 
calculated. It is found that far Asian students preferred using tens more, understand place value better. It is claimed that the language might be an effective factor on cross-national performance level. The characteristics of Turkish number words are between far Asian and Western language groups (see Table 1) and Turkey is at a lower level in cross-national test results, such as TIMSS (2007, 1999). While Western languages are unsystematic and far Asian languages are very systematic, the Turkish language is systematic for numbers between ten and twenty but not systematic for decades including twenty. This study will add the results of Turkey to the original research results, so will get a more general interpretation about the effect of language on mathematical performance.

Table 1. Number Names in Seven Languages

\begin{tabular}{|c|c|c|c|c|c|c|c|}
\hline Number & English & French & Swedish & Chinese & Japanese & Korean & Turkish \\
\hline 1 & One & Un, une & En,ett & $\mathrm{Yi}$ & İchi & İl & Bir \\
\hline 2 & Two & Deux & Två & $\mathrm{Er}$ & $\mathrm{Ni}$ & $\mathrm{Ee}$ & İki \\
\hline 3 & Three & Trois & Tre & San & San & Sam & Üç \\
\hline 4 & Four & Quatre & Fyra & $\mathrm{Si}$ & Shi & Sah & Dört \\
\hline 5 & Five & Cinq & Fem & $\mathrm{Wu}$ & Go & $\mathrm{Oh}$ & Beş \\
\hline 6 & Six & Six & Sex & Liu & Roku & Yook & Alt1 \\
\hline 7 & Seven & Sept & Sju & Qi & Shichi & Chil & Yedi \\
\hline 8 & Eight & Huit & Åtta & $\mathrm{Ba}$ & Hachi & Pal & Sekiz \\
\hline 9 & Nine & Neuf & Nio & Jiu & Kyu & Goo & Dokuz \\
\hline 10 & Ten & Dix & Tio & Shi & Juu & Shib & On \\
\hline 11 & Eleven & Onze & Elva & Shi-yi & Juu-ichi & Shib-il & On bir \\
\hline 12 & Twelve & Douze & Tolv & Shi-er & Juu-ni & Shib-ee & On iki \\
\hline 13 & Thirteen & Treize & Tretton & Shi-san & Juu-san & Shib-sam & On üç \\
\hline 14 & Fourteen & Quatorze & Fjorton & Shi-si & Juu-shi & Shib-sah & On dört \\
\hline 15 & Fifteen & Quinze & Femton & Shi-wu & Juu-go & Shib-oh & On beş \\
\hline 16 & Sixteen & Seize & Sexton & Shi-liu & Juu-roku & $\begin{array}{l}\text { Shib- } \\
\text { yook }\end{array}$ & On altı \\
\hline 17 & Seventeen & Dix-sept & Sjutton & Shi-qi & Juu-shichi & Shib-chil & On yedi \\
\hline 18 & Eighteen & Dix-huit & Arton & Shi-ba & Juu-hachi & Shib-pal & On sekiz \\
\hline 19 & Nineteen & Dix-neuf & Nitton & Shi-jiu & Juu-kyu & Shib-goo & $\begin{array}{l}\text { On } \\
\text { dokuz }\end{array}$ \\
\hline 20 & Twenty & Vingt & Tjugo & Er-shi & Ni-juu & ee-shib & Yirmi \\
\hline 21 & $\begin{array}{l}\text { Twenty- } \\
\text { one }\end{array}$ & Vingt-et un & Tjugoett & $\begin{array}{l}\text { Er-shi- } \\
\text { yi }\end{array}$ & $\begin{array}{l}\text { Ni-juu- } \\
\text { ichi }\end{array}$ & ee-shib-il & Yirmi bir \\
\hline 22 & $\begin{array}{l}\text { Twenty- } \\
\text { two }\end{array}$ & Vingt-deux & Tjugotva & $\begin{array}{l}\text { Er-shi- } \\
\text { er }\end{array}$ & Ni-juu-ni & $\begin{array}{l}\text { ee-shib- } \\
\text { ee }\end{array}$ & Yirmi iki \\
\hline 30 & Thirty & Trente & Trettio & San-shi & San-juu & Sam-shib & Otuz \\
\hline 40 & Forty & Quarante & Fyrtio & Si-shi & Shi-juu & Sah-shib & Kirk \\
\hline 50 & Fifty & Cinquante & Femtio & Wu-shi & Go-juu & Oh-shib & Elli \\
\hline 60 & Sixty & Soixante & Sextio & Liu-shi & Roku-juu & $\begin{array}{l}\text { Yook- } \\
\text { shib }\end{array}$ & Altmış \\
\hline 70 & Seventy & Soixante-dix & Sjuttio & Qi-shi & Shichi-juu & Chil-shib & Yetmiş \\
\hline 80 & Eighty & Quatre-vingts & Åttio & Ba-shi & Hachi-juu & Pal-shib & Seksen \\
\hline 90 & Ninety & $\begin{array}{l}\text { Quatre-vingt- } \\
\text { dix }\end{array}$ & Nittio & Jiu-shi & Kyu-juu & Goo-shib & Doksan \\
\hline
\end{tabular}

Source: Adapted from Miura, Okamoto, Kim, Chang, Steere \& Fayol (1994) 


\section{Subjects}

\section{METHOD}

Similar to Miura et al.'s (1994) study, all students of the current study were from a public school in a middle class neighborhood in Ankara province. The students were first graders and were tested in the first half of the academic year. They have not seen the base-ten blocks yet. In Miura et al.'s (1994) study there were 24 children from the United States (13 girls and 11 boys) with a mean age of 82 months, 23 children in France (13 girls and 10 boys) with a mean age of 75 months, 23 children in Sweden (14 girls and 9 boys) with a mean age of 87 months, 25 children in China (15 girls and 10 boys) with a mean age of 79 months, 20 children in Japan (10 girls and 10 boys) with a mean age of 77 months, 24 children in Korea (10 girls and 14 boys) with a mean age of 85 months. A relatively comparable sample was used in Turkey. So, the current study has been done with 47 children in Turkey ( 26 girls and 21 boys) with a mean age of 86 months.

\section{Procedure}

Children were tested individually by graduate students majoring in mathematics education. They were trained about how to do the experiment and were given structured interview protocols. Children were introduced Base 10 blocks which are designed so that 10 unit blocks are equal to 1 ten block, which is a rod (See Figure 1). Only tens and ones were used in the study. They were told that they can construct numbers with those blocks. Additionally, the experimenter counted ten unit blocks, put them side by side and showed the children that it was equal to a ten block. Then the children were asked to construct the numerals $(2,7,11,13,28,30,42)$ shown one at a time on a card by the experimenter, with the blocks. First, two practices were done with the numerals 2 and 7, to see if the children understood the process. Then, the numerals 11, 13, 28, 30, 42 were presented on cards one by one in a random order.

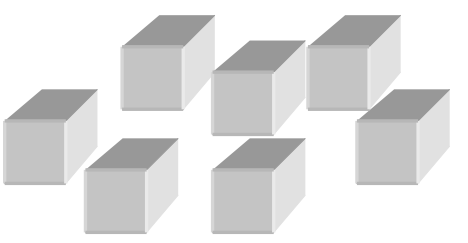

Figure 1. Base-ten blocks 
There were two trials for each number. After the first trial, the children were reminded that ten unit blocks were equal to one ten block. Their first constructions were shown and they were asked if they can make a different construction of the same number. The responses were coded as (a) one-toone collection - if only unit blocks were used, (b) canonical Base 10 representation - if adequate (used the most tens possible) tens blocks were used, (c) non-canonical Base 10 representation - if tens blocks were used fewer then canonical, and (d) incorrect - if the construction did not represent the number asked.

\section{RESULTS}

This study investigated the claim that the superior mathematics performance of students from far Asian countries may be due in part to differences in cognitive representation of number that is affected by numerical language characteristics differentiating Asian and non-Asian language groups (Miura et al., 1994). Since the Turkish language characteristics were in between the Western and far Asian languages in terms of representing the base-ten structure of the number system, we hypothesized that the Turkish students should perform below the far Asian students but above their Western counterparts.

Table 2 shows the mean number of representations in each category for the seven language groups for each trial of five numerals. The two trials are complementary. It means if a type of representation is used in one of the trials the students were asked to use a different representation in the other trial.

\section{Trial 1}

When Table 2 is examined, it is seen that Chinese, Korean and Japanese children preferred using canonical constructions more. On the other hand, the US, Swedish and French children preferred one-to-one collection more. Turkish students are between these two groups. Turkish children preferred using canonical constructions much less than China, Korea and Japan, but moderately more than the United States, Sweden and France.

\section{Trial 2}

In the second trial, Chinese, Korean and Japanese students tended towards one-to-one and non-canonical collections. French and Swedish students tended towards canonical representations. Although the US children 
used more canonical constructions in this trial than they did in the first trial, they mostly gave incorrect responses. Turkish students were more likely than the first trial to use canonical and non-canonical constructions, and got higher scores than the US students, but lower scores than the other countries.

Across the two trials, $100 \%$ of the Korean, $84 \%$ of the Chinese, $67 \%$ of the Japanese, $65 \%$ of the Swedish, 35\% of the French, 32\% of the Turkish, and $8 \%$ of the US children used a canonical construction to represent all five numbers. All of the Chinese, Korean and Japanese students used at least one canonical construction. In contrast, $50 \%$ of the US children, $22 \%$ of the Swedish children, $21 \%$ of the Turkish children, and $4 \%$ of the French children used no canonical constructions at all.

The groups also differed in their ability to make two different correct constructions for the five numbers. The US children $(\mathrm{M}=1.58)$ were less successful than were the Turkish $(M=3.13)$, Swedish $(M=3.65)$, French $(\mathrm{M}=4.04)$, Chinese $(\mathrm{M}=4.76)$, Japanese $(\mathrm{M}=4.80)$ and Korean $(\mathrm{M}=4.88)$ children. Turkey was more successful than the United States, but less successful than the other countries in this respect.

Table 2. Mean Number of Representations in Each Category for the Seven Groups

\begin{tabular}{|c|c|c|c|c|c|c|c|}
\hline & $\begin{array}{l}\text { USA } \\
(\mathrm{N}=24)\end{array}$ & $\begin{array}{l}\text { France } \\
(\mathrm{N}=23)\end{array}$ & $\begin{array}{l}\text { Sweden } \\
(\mathrm{N}=23)\end{array}$ & $\begin{array}{l}\text { China } \\
(\mathrm{N}=25)\end{array}$ & $\begin{array}{l}\text { Japan } \\
(\mathrm{N}=25)\end{array}$ & $\begin{array}{l}\text { Korea } \\
(\mathrm{N}=24)\end{array}$ & $\begin{array}{l}\text { Turkey } \\
(\mathrm{N}=47) \\
\end{array}$ \\
\hline \multicolumn{8}{|l|}{ Trial 1} \\
\hline $\begin{array}{r}\text { Canonical } \\
\text { Representation }\end{array}$ & 0,38 & 0.39 & 0.57 & 4.04 & 3.75 & 4.83 & 1.00 \\
\hline $\begin{array}{r}\text { Non canonical } \\
\text { rep. }\end{array}$ & 0.04 & 0.26 & 0 & 0.44 & 0.70 & 0.13 & 0.19 \\
\hline One to one rep. & 4.13 & 3.96 & 4.44 & 0.48 & 0.45 & 0.04 & 3.15 \\
\hline Trial $2^{\text {incorrect }}$ & 0.46 & 0.39 & 0 & 0.04 & 0.10 & 0 & 0.66 \\
\hline $\begin{array}{r}\text { Canonical } \\
\text { Representation }\end{array}$ & 1.21 & 3.00 & 2.87 & 0.76 & 0.60 & 0.17 & 1.66 \\
\hline $\begin{array}{r}\text { Non canonical } \\
\text { rep. }\end{array}$ & 0.33 & 0.91 & 0.35 & 1.96 & 1.65 & 1.96 & 0.83 \\
\hline $\begin{array}{r}\text { One to one rep. } \\
\text { incorrect }\end{array}$ & $\begin{array}{l}0.17 \\
3.29\end{array}$ & $\begin{array}{l}0.26 \\
0.83\end{array}$ & $\begin{array}{l}0.44 \\
1.35\end{array}$ & $\begin{array}{l}2.08 \\
0.20\end{array}$ & $\begin{array}{l}2.55 \\
0.20\end{array}$ & $\begin{array}{l}2.75 \\
0.13\end{array}$ & $\begin{array}{l}1.72 \\
0.79\end{array}$ \\
\hline Trial 1+ Trial 2 & & & & & & & \\
\hline Canonical total & 1.59 & 3.39 & 3.44 & 4.80 & 4.35 & 5.00 & 2.66 \\
\hline
\end{tabular}

Note: This table is adapted from Miura et al. (1994). In order to make the line by line comparison of the data easier the currently collected Turkish data were added in the last column of the table. 


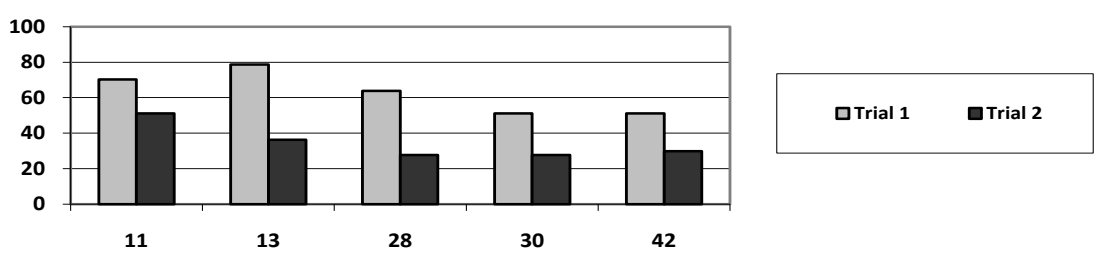

Figure 2. Percentages of canonical representations of Turkish students for different numbers

In Turkish language, there is a consistency with Base-Ten structure in tens but not in other decades. For example 20 is one separate word (yirmi) that has no similarity with two-ten. Therefore, we looked at the performance of students for each individual number. Figure 2 shows if there is a difference between the results of the tens and the other numbers (twenties, thirties, forties). According to the graph, the percentages of canonical representation of the numbers in tens are higher than the other numbers. But in general, there is a fall in the percentages as the numbers get larger. So, it is not clear whether the consistency with Base-Ten increased the performance in the numbers 11 and 13 or the negative effect of dealing with larger numbers decreased the performance in the numbers 28,30 , and 42 .

\section{DISCUSSION}

According to the results, initial preferences of children from China, Korea and Japan were canonical constructions. On the other hand, children from France, Sweden and the United States initially preferred one-to-one collections. Turkish children's preferences were between these two groups, but closer to the second group; France, Sweden and the US. It was the US participants who preferred using canonical constructions least. In the second trial, since we asked the children to make a different representation for the same numbers, many children from the Western countries make incorrect representations while the far Asian students used non canonical and one to one correct representations. The use of canonical and other representations did not make a consistent pattern.

When total values for using canonical constructions across the two trials are examined, it is seen that the Asian countries are more successful again. Among the other countries, Turkey is more successful than the US, but less from France and Sweden. The order is the same when the performance of 
constructing the numbers with two different correct representations is considered.

Considering the Turkish language and Turkish students' performances, the current study could not find a strong evidence to support the Miura et al.'s (1994) hypothesis that the systematic structure of a language contributes mathematical learning of children nor it found any counter evidence to refute the hypothesis. According to this hypothesis numerical language characteristics have a significant effect on Asian children's performances. However, Turkey which has a numerical language characteristics between the Asian and Western language groups should have had a performance level between these two groups. Turkish students generally had higher scores than the Americans and lower values than Swedish, French, Chinese, Korean and Japanese students, except the canonical construction means of the first trial.

Turkey is below all of these countries in the cross-national performance test results such as TIMSS and PISA studies. However, according to the results of this research, it is between the US and the other countries. So, when all these findings are considered, the claim that numerical language has a significant effect on both understanding base 10 and cross-national mathematical performance becomes debatable. Instead, effects like cultural characteristics or system of education might be more influential. For instance, Zhou, Peverly, and Lin (2005) state that Chinese children are not only successful in numbers and arithmetic, which can be effected by language, but also successful in geometry, problem solving and logic? They explain the reasons of this situation as valuation of mathematics, cultural differences, and characteristics of teachers.

It should also be considered whether the differences between the Far Asian and Western countries in arithmetical abilities are a recent phenomenon or they have a historical background. Geary, Salthouse, Chen, and Fan (1996) claimed that the difference has been in existence in recent decades. They compared young and old Chinese and American individuals. They were given tests of arithmetic. Chinese youngsters outperformed Americans, but there was not a significant difference for the elders. So the researchers concluded that the advantage of far Asian individuals over their American peers in arithmetical abilities did not exist 60 years ago. Considering the fact that the languages of these countries have been the same for 60 years, there should be other reasons more effective than language for the differences that exist now.

This study does not prove that the language characteristics have no effect on mathematical performance, but it claims that it may not be a long lasting significant effect. Although Turkish language has more advantages than the Western languages in terms of base-ten representations, Turkish 
first graders have almost the same performance in the initial understanding of place value and lower performance than their Western and far Asian peers in cross-national studies. This might present evidence for effective factors different from language in mathematical performance. Therefore, it can be claimed that besides language support, the East Asian countries have a high mathematical performance with the effects of some factors that should be investigated like valuation of mathematics, quality of education, cultural characteristics etc.

For practice, although it seems to have a minimal effect, the language characteristics in representing base-ten and other mathematical structures such as fractions can be used in classroom activities. For example; emphasizing the "tens" (ten-one instead of tenone) in reading the multi-digit numbers may help students realize the ten-based grouping in a number rather than treating a multi-digit number as a whole or a collection of ones.

\section{REFERENCES}

Fuson, K.C. (1990). Conceptual strategies for multiunit numbers: Implications for learning and teaching multidigit addition, subtraction, and place value. Cognition and Instruction, 7, 343-403.

Fuson, K. C., \& Kwon, Y. (1992a). Korean children's single-digit addition and subtraction: Numbers structured by ten. Journal for Research in Mathematics Education, 23, 148-165.

Fuson, K. C., \& Kwon, Y. (1992b). Korean children's understanding of multi-digit addition and subtraction. Child Development, 63, 491-506.

Geary, D. C. (1996). International differences in mathematical achievement: Their nature, causes and consequences. Current Directions in Psychological Science, 5(5), 133-137.

Geary, D. C., Bow-Thomas, C. C., Liu, F., \& Siegler, R. S. (1996). Development of arithmetical competencies in Chinese and American children: Influence of age, language and schooling. Child Development, 67, 2022-2044.

Geary, D. C., Salthouse, T. A., Chen, G. P., \& Fan, L. (1996). Are East Asian versus American differences in arithmetical ability a recent phenomenon? Developmental Psychology, 32(2), 254-262.

Hess, R.D., Chang, C.M. \& McDevitt, T. M: (1987), Cultural variations in family beliefs about children's performance in mathematics: Comparisons among People's Republic of China, Chinese-American, and Caucasian-American families, Journal of Educational Psychology 79(2), 179-188. 
Huntsinger, C. S., Jose, P. E., Liaw, F. R., \& Ching, W. D. (1997) Cultural differences in early mathematics learning: A comparison of EuroAmerican, Chinese-American, and Taiwan-Chinese families. International Journal of Behavioral Development, 21, 371-388.

Judson, T. W. (1999). Japan: A different model of mathematics education. Contemporary Issues in Mathematics Education, 36, 75-81.

Miura, I., T., Okamoto, Y., Kim, C. C., Chang, C. M., Steere, M., \& Fayol, M. (1994). Comparisons of children's cognitive representation of number: China, France, Japan, Korea, Sweden and the United States. International Journal of Behavioral Development, 17, 401-411.

Miura, I., T., Okamoto, Y., Vlahovic-Stetic, V., Kim, C. C., \& Han J. H. (1999). Language supports for children's understanding of numerical fractions: Cross-national comparisons. Journal of Experimental Child Psychology, 74, 356-365.

PISA. (2009). PISA 2009 Results: What Students Know and Can Do? Student Performance in Reading, Mathematics and Science. Retrieved on 12-January-2011, at URL:

http://browse.oecdbookshop.org/oecd/pdfs/browseit/9810071E.PDF

PISA (2003). Learning for Tomorrows World: First Results from PISA 2003, OECD. Retrieved on 12-January-2011, at URL: http://www.oecd.org/dataoecd/1/60/34002216.pdf

TIMSS. (2007). TIMSS 2007 International Mathematics Report: Findings from IEA's Trends in International Mathematics and Science Study at the Fourth and Eighth Grades. Retrieved on 12-January-2011, at URL: http://timss.bc.edu/timss2007/intl_reports.html

TIMSS. (2003). IEA's TIMSS 2003 International Report on Achievement in the Mathematics Cognitive Domains. International Association for the Evaluation of Educational Achievement (IEA). Retrieved on 12January-2011, at URL:

http://timss.bc.edu/PDF/t03_download/T03INTLMATRPT.pdf

TIMSS. (1999). International Mathematics Report, Findings from IEA's Repeat of the Third International Mathematics and Science Study at the Eight Grade. Retrieved on 12-March-2001, at URL: http://timss.bc.edu/timss1999i/pdf/T99i_Math_TOC.pdf.

Zhou, Z., Peverly, S. T., \& Lin, J. (2005). Understanding early mathematical competencies in American and Chinese children. School Psychology International, 26, 413-427. 